\title{
PENGARUH LEVERAGE DAN PROFITABILITAS TERHADAP NILAI PERUSAHAAN PADA PERUSAHAAN SUB SEKTOR KIMIA YANG TERDAFTAR DI BURSA EFEK INDONESIA
}

\author{
Oleh : \\ Desiyusliani Lubis \\ S1 Akuntansi \\ Liper Siregar, Jubi, Astuti
}

Abstrak

Tujuan dari penelitian ini adalah: Untuk mengetahui gambaran leverage, profitabilitas, dan nilai perusahaan serta pengaruh leverage dan profitabilitas terhadap nilai perusahaan pada Perusahaan Sub Sektor Kimia yang terdaftar di Bursa Efek Indonesia. Desain penelitian yang digunakan adalah penelitian kepustakaan. Teknik analisis data yang digunakan dalam penelitian ini seperti: uji asumsi klasik, analisis deskriptif kualitatif dan kuantitatif.

Hasil penelitian menunjukkan $\hat{Y}=-0,055+1,502 X_{1}+6,689 X_{2}$. Koefisien korelasi sebesar 0,463 dan nilai $R$ sebesar 0,214 . Hasil uji $F$ menunjukkan bahwa $F_{\text {hitung }}>F_{\text {tabel }}(5,051>3,25)$ atau tingkat signifikansi $0,011<0,05$ berarti leverage dan profitabilitas berpengaruh signifikan terhadap nilai perusahaan pada Perusahaan Sub Sektor Kimia yang terdaftar di Bursa Efek Indonesia. Hasil uji t untuk leverage $t_{\text {hitung }}>t_{\text {tabel }}(2,162>2,02619)$ atau Sig.<alpha $(0,037<0,05)$, berarti leverage berpengaruh signifikan terhadap nilai perusahaan pada Perusahaan Sub Sektor Kimia yang terdaftar di Bursa Efek Indonesia. Hasil uji $t$ untuk profitabilitas $t_{\text {hitung }}>t_{\text {tabel }}(3,134>2,026)$ atau Sig. $<a l p h a(0,003$ $<0,05$ ), berarti kebijakan dividen berpengaruh signifikan terhadap nilai perusahaan pada Perusahaan Sub Sektor Kimia yang terdaftar di Bursa Efek Indonesia.

Saran yang dapat diberikan adalah sebaiknya perusahaan tetap mengoptimalkan penggunaan dana dalam perusahaan dan meningkatkan penjualan. Selain itu, bagi peneliti selanjutnya sebaiknya menambah periode penelitian dan menggunakan atau menambah variabel penelitian yang lainnya.

Kata Kunci: Leverage, Profitabilitas, dan Nilai Perusahaan.

Abstract

The purpose of this research is to know the description of leverage, profitability and firm's value and to determine influence of leverage and profitability to the firm's value at Firm in Chemical SubSector listed on the Indonesia Stock Exchange. The research design used in this research is library research. The analysis data technique used in this research are assumption classic test, qualitative and quantitative descriptive analysis

The result shown $\hat{Y}=-0,055+1,502 X_{1}+6,689 X_{2}$. Correlation coefficient of $r=0,463$ and $R$ value of 0,214 . The simultaneous test results $F_{\text {count }}>F_{\text {table }}(5,051>3,25)$ or significant level obtained $0,011<0,05$ means leverage and profitability have significant effect on the firm's value at Firm in Chemical Sub-Sector listed on the Indonesian Stock Exchange. The t-test results show leverge has $t_{\text {count }}>t_{\text {table }}(2,162>2,02619)$ or significance level $0,037<0,05$, means leverage has significant effect on firm's value at Firm in Chemical Sub-Sector listed on the Indonesian Stock Exchange. The t-test results that profitability to $t_{\text {count }}>t_{\text {table }}(3,134>2,026)$ or significance level $0,003<0,05$, means profitability has significant effect on firm's value at Firm in Chemical Sub-Sector listed on the Indonesian Stock Exchange.

The result of this research suggests management companies should still optimize the use of corporate funds and increase sales. And for the next researchers should use or add to other research variables.

Keywords: Leverage, Profitability, and Firm Value

\section{A. PENDAHULUAN}

\section{Latar Belakang Masalah}

Persaingan usaha yang semakin ketat mendorong perusahaan untuk meningkatkan kinerja perusahaan dan nilai perusahaan. Dengan meningkatkan kinerja dan nilai perusahaan akan menambah keyakinan para investor untuk berinvestasi di perusahaan tersebut dan dapat meningkatkan kemakmuran para pemilik perusahaan maupun pemegang saham. Fluktuasi nilai perusahaan dapat dipengaruhi oleh kemampuan perusahaan dalam menutupi utangnya atau sering disebut leverage. Perusahaan dengan laba yang lebih tinggi akan mampu membayar dividen tinggi, sehingga sampai tingkat dimana utang yang lebih tinggi menaikkan EPS yang diharapkan, leverage akan meningkatkan harga saham.

Selain dipengaruhi oleh leverage, nilai perusahaan juga dipengaruhi oleh profitabilitas. Jika rasio profitabilitas terlihat baik dan jika kondisi ini berjalan terus menerus

\begin{tabular}{llll}
\hline \hline Jurnal SULTANIST & ISSN : 2338-4328 & Vol. 6, No. 1, JUNI 2018 & 63
\end{tabular}


secara stabil maka rasio nilai pasar juga akan tinggi.

Tabel 1

Gambaran Price to Book Value (PBV) pada Perusahaan Sub Sektor Kimia Periode 2012-2016

\begin{tabular}{|c|l|c|c|c|c|c|c|}
\hline $\begin{array}{c}\text { Kode } \\
\text { Emite } \\
\mathbf{n}\end{array}$ & $\begin{array}{l}\text { Nama } \\
\text { Perusahaan }\end{array}$ & $\mathbf{2 0 1 2}$ & $\mathbf{2 0 1 3}$ & $\mathbf{2 0 1 4}$ & $\mathbf{2 0 1 5}$ & $\mathbf{2 0 1 6}$ & $\begin{array}{c}\text { Rata-Rata } \\
\text { (Per } \\
\text { Perusahaan }\end{array}$ \\
\hline BRPT & $\begin{array}{l}\text { PT Barito } \\
\text { Pasifi, }\end{array}$ & 0,340 & 0,271 & 0,198 & 0,077 & 0,775 & $\mathbf{0 , 3 3 2}$ \\
\hline BUDI & $\begin{array}{l}\text { PT Budi } \\
\text { Starch \& } \\
\text { Sweetener, } \\
\text { Tbk }\end{array}$ & 0,580 & 0,548 & 0,521 & 0,312 & 0,407 & $\mathbf{0 , 4 7 4}$ \\
\hline DPNS & $\begin{array}{l}\text { PT Duta } \\
\text { Pertiwi } \\
\text { Nusantara, } \\
\text { Tbk }\end{array}$ & 0,874 & 0,778 & 0,560 & 0,607 & 0,600 & $\mathbf{0 , 6 8 4}$ \\
\hline EKAD & $\begin{array}{l}\text { PT } \\
\text { Ekadharma } \\
\text { International } \\
\text { ITk }\end{array}$ & 1,588 & 1,456 & 1,628 & 1,086 & 1,185 & $\mathbf{1 , 3 8 9}$ \\
\hline $\begin{array}{l}\text { PT Intan } \\
\text { Wijaya } \\
\text { International } \\
\text { Trk }\end{array}$ & 0,383 & 0,345 & 0,314 & 0,363 & 0,345 & $\mathbf{0 , 3 5 0}$ \\
\hline SRSN & $\begin{array}{l}\text { PT Indo } \\
\text { Acitama, } \\
\text { Tbk }\end{array}$ & 1,118 & 1,055 & 1,004 & 0,968 & 0,936 & $\mathbf{1 , 0 1 7}$ \\
\hline TPIA & $\begin{array}{l}\text { PT Chandra } \\
\text { Asri } \\
\text { Petrochemical, } \\
\text { Tbk }\end{array}$ & 2,105 & 0,947 & 0,918 & 0,940 & 4,440 & $\mathbf{1 , 8 7 0}$ \\
\hline UNIC & $\begin{array}{l}\text { PT Unggul } \\
\text { Indah } \\
\text { Cahaya, Tbk }\end{array}$ & 0,465 & 0,338 & 0,279 & 0,235 & 0,342 & $\mathbf{0 , 3 3 2}$ \\
\hline Rata-Rata (Per Tahun) & $\mathbf{0 , 9 3 2}$ & $\mathbf{0 , 7 1 7}$ & $\mathbf{0 , 6 7 8}$ & $\mathbf{0 , 5 7 3}$ & $\mathbf{1 , 1 2 9}$ & $\mathbf{0 , 8 0 6}$ \\
\hline
\end{tabular}

Sumber: www.idx.co.id, data diolah

Dari Tabel 1 di atas dapat dilihat bahwa nilai rata-rata Price to Book Value (PBV) periode 2012-2016 mengalami fluktuasi dan cenderung meningkat. Nilai rata-rata PBV keseluruhan adalah sebesar 0,806 , berada di bawah 1 artinya harga pasar saham perusahaan dinilai lebih rendah dari nilai bukunya.

\section{Rumusan Masalah}

a. Bagaimana gambaran leverage, profitabilitas, dan nilai perusahaan pada Perusahaan Sub Sektor Kimia yang terdaftar di Bursa Efek Indonesia.

b. Bagaimana pengaruh leverage dan profitabilitas terhadap nilai perusahaan pada Perusahaan Sub Sektor Kimia yang terdaftar di Bursa Efek Indonesia baik secara simultan maupun parsial.

\section{Tujuan Penelitian}

a. Untuk mengetahui gambaran umum leverage, profitabilitas, dan nilai perusahaan pada Perusahaan Sub Sektor Kimia yang terdaftar di Bursa Efek Indonesia.

b. Untuk mengetahui pengaruh leverage dan profitabilitas terhadap nilai perusahaan pada Perusahaan Sub Sektor Kimia yang terdaftar di Bursa Efek Indonesia baik secara simultan maupun parsial.

\section{Metodologi Penelitian}

Penelitian ini menggunakan data sekunder, dengan cara mengakses dari situs http://www.idx.co.id. Desain penelitian yang digunakan adalah penelitian kepustakaan (library research). Teknik analisis dalam penelitian ini adalah Uji Asumsi Klasik, Analisa
Deskriptif Kualitatif, Analisa Deskriptif Kuantitatif.

\section{B. LANDASAN TEORI}

\section{Laporan Keuangan}

Menurut Baridwan (2004:17), laporan keuangan merupakan ringkasan dari suatu proses pencatatan, merupakan suatu ringkasan dari transaksi-transaksi keuangan yang terjadi selama tahun buku yang bersangkutan.

Menurut Hery (2009:6), laporan keuangan pada dasarnya adalah hasil dari proses akuntansi yang dapat digunakan sebagai alat untuk mengkomunikasikan data keuangan atau aktivitas perusahaan kepada pihak-pihak yang berkepentingan.

Menurut Martani, dkk (2012:9), secara umum tujuan laporan keuangan adalah :

1. Menginformasikan posisi keuangan, kinerja serta perubahan posisi keuangan suatu entitas yang bermanfaat bagi sejumlah besar pemakai dalam pengambilan keputusan ekonomi.

2. Menunjukkan apa yang telah dilakukan manajemen(stewardship) dan pertanggungjawaban sumber daya yang dipercayakan kepadanya.

3. Memenuhi kebutuhan bersama sebagian besar pemakai.

4. Menyediakan pengaruh keuangan dari kejadian dimasa lalu.

\section{Analisis Rasio Keuangan}

Menurut Sudana (2011:20), analisis laporan keuangan penting dilakukan untuk mengetahui kekuatan dan kelemahan suatu perusahaan. Informasi ini diperlukan untuk mengevaluasi kinerja yang dicapai manajemen perusahaan dimasa yang lalu, dan juga untuk bahan pertimbangan dalam menyusun rencana perusahaan kedepan

Menurut Kasmir (2012:66), Agar laporan keuangan menjadi lebih berarti sehingga dapat dipahami dan dimengerti oleh berbagai pihak, perlu dilakukan analisis laporan keuangan.

\section{Rasio Keuangan}

Menurut Kasmir (2010:93), rasio keuangan adalah kegiatan membandingkan angka-angka yang ada dalam laporan keuangan dengan cara membagi satu angka dengan angka lainnya.

Menurut Keown, et. al. (2008:74), rasio keuangan merupakan penulisan ulang data akuntansi ke dalam bentuk perbandingan dalam rangka mengidentifikasi kekuatan dan kelemahan keuangan perusahaan.

\section{Leverage}

Penggunaan utang akan memberikan manfaat bagi perusahaan berupa bunga sebagai pengurang pajak. Menurut Kasmir 
(2012:151), rasio solvabilitas atau leverage ratio merupakan rasio yang digunakan untuk mengukur sejauh mana aktiva perusahaan dibiayai oleh utang.

Menurut Harahap (2008:306), rasio leverage menggambarkan hubungan antara utang perusahaan terhadap modal maupun aset.

Menurut Brigham dan Joel (2011:155), ada empat faktor yang mempengaruhi leverage, yaitu sebagai berikut :

1) Risiko Usaha

2) Posisi Pajak Perusahaan

3) Fleksibilitas Keuangan

4) Konservatisme atau Keagresifan Manajeria

\section{Profitabilitas}

Menurut Kasmir (2012:196), rasio profitabilitas merupakan rasio yang digunakan untuk menilai kemampuan perusahaan dalam mencari keuntungan. Selain digunakan untuk memberikan penilaian kemampuan perusahaan, rasio ini juga menjelaskan ukuran tingkat efektivitas manajemen suatu perusahaan. Hal ini diinformasikan melalui laba hasil dari penjualan dan pendapatan investasi.

Menurut Munawir (2004:86), profitability suatu perusahaan dapat diukur dengan menghubungkan antara keuntungan atau laba yang diperoleh dari kegiatan pokok perusahaan dengan kekayaan atau assets yang digunakan untuk menghasilkan keuntungan tersebut.

Menurut Riyanto (2009:37), ada beberapa faktor yang perlu diperhatikan dalam menentukan profitabilitas perusahaan, yaitu :

1) Penjualan

2) Efisiensi Modal Kerja

3) Profit margin

4) Struktur Moda

\section{Nilai Perusahaan}

Menurut Brigham dan Joel (2012:150), rasio nilai pasar (market value ratio) yang berhubungan dengan harga saham perusahaan terhadap laba, arus kas dan nilai buku per sahamnya. Rasio ini memberikan indikasi bagi manajemen tentang bagaimana pandangan investor terhadap resiko dan prospek perusahaan dimasa depan.

Menurut Keown, et. al. (2004:470), nilai perusahaan adalah nilai pasar atas surat berharga, utang dan ekuitas perusahaan yang beredar.

Menurut Brigham dan Joel (2001:158), faktor-faktor eksternal yang mempengaruhi nilai perusahaan adalah :

1) Tingkat Inflasi

2) Tingkat Bunga

\section{Pengaruh Leverage dan Profitabilitas} terhadap Nilai Perusahaan
Menurut Brigham dan Joel (2011:171), perusahaan dengan laba yang lebih tinggi akan mampu membayar dividen tinggi, sehingga sampai tingkat dimana utang yang lebih tinggi menaikkan EPS yang diharapkan, leverage akan meningkatkan harga saham. Namun, tingkat utang yang lebih tinggi juga akan meningkatkan risiko perusahaan, dan hal ini akan meningkatkan biaya ekuitas dan mengakibatkan terjadinya penurunan pada harga saham. Oleh karena itu, keputusan digunakannya utang mengharuskan perusahaan membandingkan antara perkiraan pengembalian yang lebih tinggi dengan meningkatnya risiko.

Menurut Brigham dan Joel (2012:150), jika rasio likuiditas, manajemen aset, manajemen utang, dan profitabilitas terlihat baik dan jika kondisi ini berjalan terus menerus secara stabil maka rasio nilai pasar juga akan tinggi, harga saham kemungkinan tinggi sesuai dengan yang diperkirakan, dan manajemen telah melakukan pekerjaannya dengan baik sehingga sebaiknya mendapat imabalan. Jika sebaliknya, mungkin ada perubahan yang harus dilakukan. Harga saham yang tinggi akan berpengaruh terhadap peningkatan nilai perusahaan dan sebaliknya jika harga saham turun maka akan menurunkan nilai perusahaan.

\section{PEMBAHASAN}

1. Analisis

a. Analisis Deskripsi Kualitatif

1) Gambaran Leverage pada Perusahaan Sub Sektor Kimia yang terdaftar di Bursa Efek Indonesia

Rata-rata Debt to Asset Ratio (DAR) pada Perusahaan Sub Sektor Kimia yang terdaftar di Bursa Efek Indonesia periode 2012-2016 dapat dilihat pada Tabel 2 .

Tabel 2

DAR pada Perusahaan Sub Sektor Kimia yang terdaftar di Bursa Efek Indonesia Periode 2012-2016

\begin{tabular}{|c|c|c|c|c|c|c|c|}
\hline $\begin{array}{l}\text { Kode } \\
\text { Emiten }\end{array}$ & $\begin{array}{c}\text { Nama } \\
\text { Perusahaan }\end{array}$ & $\begin{array}{l}2012 \\
\text { (Kali) }\end{array}$ & $\begin{array}{l}2013 \\
\text { (Kali) }\end{array}$ & $\begin{array}{l}2014 \\
\text { (Kali) }\end{array}$ & $\begin{array}{l}2015 \\
\text { (Kali) }\end{array}$ & $\begin{array}{l}2016 \\
\text { (Kali) }\end{array}$ & $\begin{array}{l}\text { Rata- } \\
\text { Rata } \\
\text { Perus } \\
\text { ahaan } \\
\text { (Kali) }\end{array}$ \\
\hline BRPT & $\begin{array}{l}\text { PT Barito } \\
\text { Pasifik, Tbk }\end{array}$ & 0,543 & 0,431 & 0,546 & 0,469 & 0,437 & 0,485 \\
\hline BUDI & $\begin{array}{l}\text { PT Budi Starch } \\
\text { \& Sweetener, } \\
\text { Tbk }\end{array}$ & 0,629 & 0,629 & 0,631 & 0,662 & 0,603 & 0,631 \\
\hline DPNS & $\begin{array}{l}\text { PT Duta } \\
\text { Pertiwi } \\
\text { Nusantara, Tbk }\end{array}$ & 0,157 & 0,129 & 0,122 & 0,121 & 0,111 & 0,128 \\
\hline EKAD & $\begin{array}{l}\text { PT Ekadharma } \\
\text { International, } \\
\text { Tbk }\end{array}$ & 0,299 & 0,308 & 0,336 & 0,251 & 0,157 & 0,270 \\
\hline $\mathrm{INCI}$ & $\begin{array}{l}\text { PT Intan } \\
\text { Wijaya } \\
\text { International, } \\
\text { Tbk }\end{array}$ & 0,125 & 0,074 & 0,073 & 0,091 & 0,098 & 0,092 \\
\hline SRSN & $\begin{array}{l}\text { PT Indo } \\
\text { Acitama, Tbk }\end{array}$ & 0,331 & 0,253 & 0,290 & 0,408 & 0,439 & 0,344 \\
\hline TPIA & $\begin{array}{l}\text { PT Chandra } \\
\text { Asri } \\
\text { Petrochemical, } \\
\text { Tbk } \\
\end{array}$ & 0,573 & 0,552 & 0,548 & 0,524 & 0,464 & 0,532 \\
\hline UNIC & $\begin{array}{l}\text { PT Unggul } \\
\text { Indah Cahaya, } \\
\text { Tbk } \\
\end{array}$ & 0,437 & 0,460 & 0,392 & 0,367 & 0,290 & 0,389 \\
\hline Rata-l & $\begin{array}{l}\text { ta per Tahun } \\
\text { (Kali) }\end{array}$ & 0,387 & 0,354 & 0,367 & 0,362 & 0,325 & 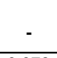 \\
\hline \multicolumn{7}{|c|}{$\begin{array}{l}\text { Nilai Minimum DAR } \\
\text { Nilai Maksimum DAR }\end{array}$} & $\begin{array}{l}0,073 \\
0,662 \\
\end{array}$ \\
\hline \multicolumn{7}{|c|}{ Rata-rata DAR Keseluruhan } & 0,359 \\
\hline
\end{tabular}


Sumber: Data diolah

Dari Tabel 2, dapat disajikan grafik sebagai berikut:

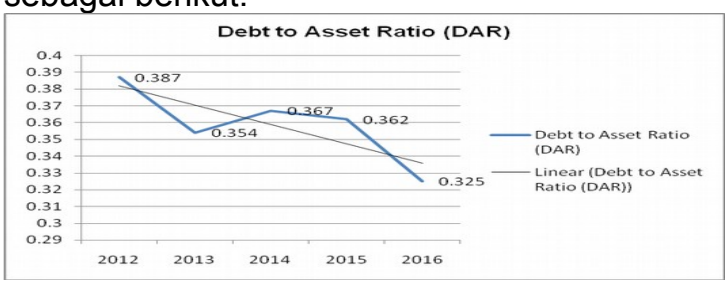

Sumber: Data Diolah (www.idx.co.id)

\section{Gambar 1}

Grafik rata-rata DAR pada Perusahaan Sub Sektor Kimia yang terdaftar di Bursa Efek Indonesia periode 2012-2016

Berdasarkan Tabel 2 dan Gambar 1 dapat dilihat rata-rata nilai DAR pada Perusahaan Sub Sektor Kimia yang terdaftar di Bursa Efek Indonesia periode 2012-2016 mengalami fluktuasi dan cenderung menurun. Hal ini menunjukkan bahwa perusahaan lebih banyak memakai pendanaan dari pihak internal perusahaan daripada pendanaan dari pihak eksternal perusahaan

Nilai minimum DAR sebesar 0,073 kali atau $7,3 \%$ pada tahun 2014. Artinya dari setiap Rp100 total aset dibiayai oleh utang sebesar Rp 7,3. Nilai maksimum DAR adalah 0,662 kali atau $66,2 \%$ pada tahun 2015 .

2) Gambaran Profitabilitas pada

Perusahaan Sub Sektor Kimia yang terdaftar di Bursa Efek Indonesia periode 2012-2016

Return on Asset (ROA) pada Perusahaan Sub Sektor Kimia yang terdaftar di Bursa Sebagai berikut :

Tabel 3

ROA pada Perusahaan Sub Sektor Kimia yang terdaftar di Bursa Efek Indonesia Periode 2012-2016

\begin{tabular}{|c|c|c|c|c|c|c|c|}
\hline $\begin{array}{c}\text { Kode } \\
\text { Emiten }\end{array}$ & $\begin{array}{c}\text { Nama } \\
\text { Perusahaa } \\
n\end{array}$ & $\begin{array}{l}2012 \\
\text { (Kali) }\end{array}$ & $\begin{array}{l}2013 \\
\text { (Kali) }\end{array}$ & $\begin{array}{l}2014 \\
\text { (Kali) }\end{array}$ & $\begin{array}{l}2015 \\
\text { (Kali) }\end{array}$ & $\begin{array}{l}2016 \\
\text { (Kali) }\end{array}$ & $\begin{array}{l}\text { Rata-Rata } \\
\text { Perusahaar } \\
\text { (Kali) }\end{array}$ \\
\hline BRPT & $\begin{array}{l}\text { PT Barito } \\
\text { Pasifik, } \\
\text { Tbk }\end{array}$ & $-0,058$ & $-0,009$ & $-0,001$ & 0,002 & 0,109 & 0,009 \\
\hline BUDI & $\begin{array}{l}\text { PT Budii } \\
\text { Starch \& } \\
\text { Sweetener, } \\
\text { Tbk }\end{array}$ & 0,002 & 0,018 & 0,012 & 0,006 & 0,013 & 0,010 \\
\hline DPNS & $\begin{array}{l}\text { PT Duta } \\
\text { Pertivi } \\
\text { Nusantara, } \\
\text { Tbk }\end{array}$ & 0,112 & 0,261 & 0,054 & 0,036 & 0,034 & 0,099 \\
\hline EKAD & $\begin{array}{l}\text { PT } \\
\text { Ekadharma } \\
\text { Internation } \\
\text { al Thk }\end{array}$ & 0,132 & 0,115 & 0,099 & 0,121 & 0,129 & 0,119 \\
\hline $\mathrm{INCl}$ & $\begin{array}{l}\text { PT Intan } \\
\text { Wijaya } \\
\text { Internation } \\
\text { al, Tbk }\end{array}$ & 0,034 & 0,076 & 0,075 & 0,100 & 0,037 & 0,064 \\
\hline SRSN & $\begin{array}{l}\text { PT Indo } \\
\text { Acitama, Tb } \\
\mathrm{k}\end{array}$ & 0,042 & 0,038 & 0,031 & 0,027 & 0,015 & 0,031 \\
\hline TPIA & \begin{tabular}{l|} 
PT Chandra \\
Asri \\
Petrochemica \\
I, Tbk
\end{tabular} & $-0,052$ & 0,006 & 0,009 & 0,014 & 0,141 & 0,024 \\
\hline UNIC & \begin{tabular}{l|} 
PT Unggul \\
Indah \\
Cahaya, \\
Tbk \\
\end{tabular} & 0,007 & 0,038 & 0,011 & $-0,004$ & 0,093 & 0,029 \\
\hline Rata-R & $\begin{array}{l}\text { oer Tahun } \\
\text { li) }\end{array}$ & 0,027 & 0,068 & 0,036 & 0,038 & 0,071 & - \\
\hline \multicolumn{7}{|c|}{ Nilai Minimum ROA } & $-0,058$ \\
\hline \multicolumn{7}{|c|}{ Nilai Maksimum ROA } & 0,261 \\
\hline \multicolumn{7}{|c|}{ Rata-rata ROA keseluruhan } & 0,048 \\
\hline
\end{tabular}

Sumber: Data diolah

Berdasarkan Tabel 3 dapat disajikan grafik sebagai berikut:

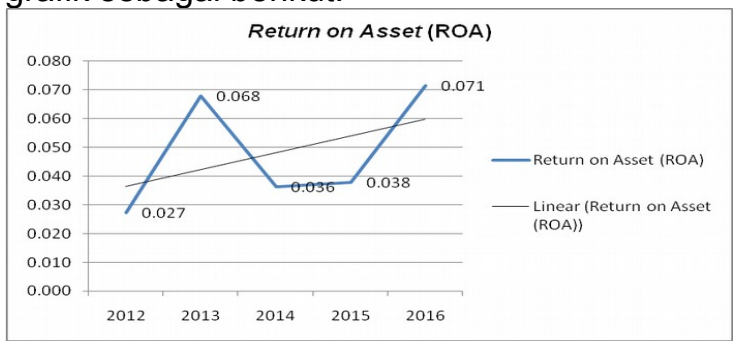

Sumber: Data Diolah (www.idx.co.id)

Gambar 2

Grafik rata-rata ROA pada Perusahaan Sub Sektor Kimia yang Terdaftar di Bursa Efek Indonesia Periode 2012-2106

Berdasarkan Tabel 3 dan Gambar 2, terlihat bahwa nilai ROA Perusahaan Sub Sektor Kimia periode 2012-2016 berfluktuasi dan cenderung meningkat. Peningkatan nilai ROA menunjukkan kemampuan perusahaan dalam menghasilkan keuntungan meningkat sehingga memberikan sinyal positif bagi investor. Hal ini menjadi daya tarik investor untuk memiliki saham perusahaan dan akan meningkatkan harga saham sehingga nilai perusahaan akan meningkat.

Nilai minimum ROA sebesar $-0,058$ atau $5,8 \%$ pada tahun 2012. Hal ini menunjukkan bahwa setiap Rp 100 aset mengalami rugi sebesar Rp 5,8. Nilai maksimum ROA sebesar 0,261 atau $21,6 \%$ pada tahun 2013 .

3) Gambaran Nilai Perusahaan pada Perusahaan Sub Sektor Kimia yang terdaftar di Bursa Efek Indonesia periode 2012-2016

Price to Book Value (PBV) pada Perusahaan Sub Sektor Kimia sebagai berikut Tabel 4

PBV pada Perusahaan Sub Sektor Kimia yang terdaftar di Bursa Efek Indonesia Periode 2012-2016

\begin{tabular}{|c|c|c|c|c|c|c|c|}
\hline $\begin{array}{c}\text { Kode } \\
\text { Emiten }\end{array}$ & $\begin{array}{c}\text { Nama } \\
\text { Perusahaan }\end{array}$ & $\begin{array}{l}2012 \\
\text { (Kali) }\end{array}$ & $\begin{array}{l}2013 \\
\text { (Kali) }\end{array}$ & $\begin{array}{l}2014 \\
\text { (Kali) }\end{array}$ & $\begin{array}{l}2015 \\
\text { (Kali) }\end{array}$ & $\begin{array}{l}2016 \\
\text { (Kali) }\end{array}$ & $\begin{array}{c}\text { Rata-Rata } \\
\text { Perusahaa } \\
n \\
\text { (Kali) }\end{array}$ \\
\hline BRPT & $\begin{array}{l}\text { PT Barito } \\
\text { Pasifik, Tbk }\end{array}$ & 0,340 & 0,271 & 0,198 & 0,077 & 0,775 & 0,332 \\
\hline BUDI & $\begin{array}{l}\text { PT Budi } \\
\text { Starch \& } \\
\text { Sweetener, } T \\
\text { bk }\end{array}$ & 0,580 & 0,548 & 0,521 & 0,312 & 0,407 & 0,474 \\
\hline DPNS & $\begin{array}{l}\text { PT Duta } \\
\text { Pertiwi } \\
\text { Nusantara, } \\
\text { Tbk }\end{array}$ & 0,874 & 0,778 & 0,560 & 0,607 & 0,600 & 0,684 \\
\hline EKAD & $\begin{array}{l}\text { PT } \\
\text { Ekadharma } \\
\text { International } \\
\text { Tbk }\end{array}$ & 1,588 & 1,456 & 1,628 & 1,086 & 1,185 & 1,389 \\
\hline $\mathrm{INCl}$ & $\begin{array}{l}\text { PT Intan } \\
\text { Wijaya } \\
\text { International } \\
\text { Tbk }\end{array}$ & 0,383 & 0,345 & 0,314 & 0,363 & 0,345 & 0,350 \\
\hline SRSN & $\begin{array}{l}\text { PT Indo } \\
\text { Acitama,Tbk }\end{array}$ & 1,118 & 1,055 & 1,004 & 0,968 & 0,936 & 1,017 \\
\hline TPIA & $\begin{array}{l}\text { PT Chandra } \\
\text { Asri } \\
\text { Petrochemical } \\
\text { Tbk }\end{array}$ & 2,105 & 0,947 & 0,918 & 0,940 & 4,440 & 1,870 \\
\hline UNIC & $\begin{array}{l}\text { PT Unggul } \\
\text { Indah } \\
\text { Cahaya Tbk } \\
\end{array}$ & 0,465 & 0,338 & 0,279 & 0,235 & 0,342 & 0,332 \\
\hline Rata- & $\begin{array}{l}\text { ta per Tahun } \\
\text { Kali) }\end{array}$ & 0,932 & 0,717 & 0,678 & 0,573 & 1,129 & - \\
\hline \multicolumn{7}{|c|}{$\begin{array}{l}\text { Nilai Minimum PBV } \\
\text { Nilai Maksimum PBV }\end{array}$} & $\begin{array}{l}, 077 \\
4,440 \\
\end{array}$ \\
\hline & & ta-rata K & eluruhar & & & & 0,806 \\
\hline
\end{tabular}

Sumber: Data diolah 
Berdasarkan Tabel 4 di atas, maka disajikan grafik PBV sebagai berikut:

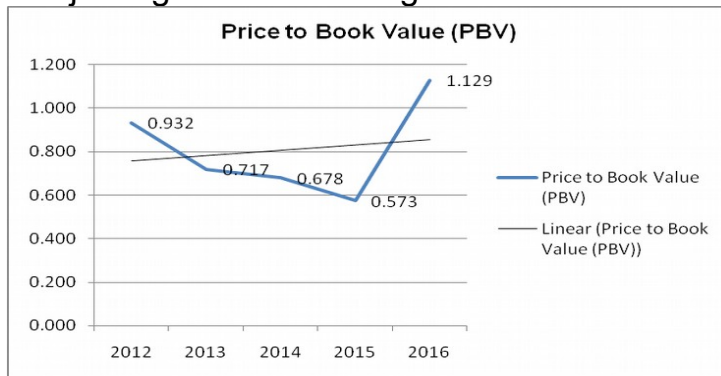

Sumber: Data Diolah (www.idx.co.id) Gambar 3

Grafik rata-rata PBV pada Perusahaan Sub Sektor Kimia yang terdaftar di Bursa Efek Indonesia Periode 2012-2016

Berdasarkan Tabel 4 dan Gambar 3 di atas terlihat bahwa nilai PBV Perusahaan Sub Sektor Kimia yang terdaftar di Bursa Efek Indonesia periode 2012-2016 berfluktuasi dan cenderung meningkat.

Nilai minimum PBV sebesar 0,077 kali di tahun 2015. Hal ini disebabkan karena rendahnya harga saham dibandingkan dengan nilai bukunya. nilai PBV lebih rendah dibandingkan nilai bukunya. Nilai maksimum PBV tahun 2016 sebesar 4,440. Hal ini disebabkan peningkatan harga saham lebih besar dibandingkan peningkatan nilai bukunya.

b. Analisis Deskrisptif Kuantitatif

1) Regresi Linier Berganda Tabel 5

Hasil Analisis Regresi Linier Berganda Coefficients

\begin{tabular}{|ll|r|r|r|}
\hline Model & \multicolumn{2}{|c|}{$\begin{array}{c}\text { Unstandardized } \\
\text { Coefficients }\end{array}$} & $\begin{array}{c}\text { Standardized } \\
\text { Coefficients }\end{array}$ \\
\cline { 2 - 5 } & \multicolumn{1}{|c|}{ B } & Std. Error & \multicolumn{1}{c|}{ Beta } \\
\hline \multirow{2}{*}{1 (Constant) } &,- 055 &, 335 & \\
& DAR & 1,502 &, 695 &, 377 \\
& ROA & 6,689 & 2,134 &, 547 \\
\hline
\end{tabular}

Dependent Variable: PBV

Sumber: Hasil Pengolahan Data

Berdasarkan Tabel 5, model persamaan regresi yang diperoleh adalah sebagai berikut: $\hat{\mathrm{Y}}=-0,055+1,502 \mathrm{X}_{1}+6,689 \mathrm{X}_{2}$

Berdasarkan model dapat diartikan bahwa leverage dan profitabilitas berpengaruh positif terhadap nilai perusahaan pada Perusahaan Sub Sektor Kimia yang terdaftar di Bursa Efek Indonesia untuk periode 2012-2016.

\section{2) Koefisien Korelasi dan Determinasi} Tabel 6

Hasil Analisis Koefisien Korelasi dan Koefisien Determinasi

Model Summary

\begin{tabular}{|l|r|r|r|r|}
\hline Model & $\mathrm{R}$ & $\mathrm{R}$ Square & $\begin{array}{c}\text { Adjusted R } \\
\text { Square }\end{array}$ & $\begin{array}{c}\text { Std. Error of } \\
\text { the Estimate }\end{array}$ \\
\hline 1 &, $463^{\mathrm{a}}$ &, 214 &, 172 &, 675138 \\
\hline
\end{tabular}

a. Predictors: (Constant), ROA, DAR

b. Dependent Variable: PBV

Sumber: Hasil Pengolahan Data
Berdasarkan Tabel 6 nilai $r=0,463$ berarti hubungan antara leverage dan profitabilitas terhadap nilai perusahaan pada Perusahaan Sub Sektor Kimia yang terdaftar di Bursa Efek Indonesia adalah sedang. Sementara koefisien determinasi (R Square) $=0,214$ berarti variabel leverage dan profitabilitas berkontribusi terhadap nilai perusahaan sebesar $21,4 \%$ dan sisanya sebesar $78,6 \%$ dijelaskan oleh variabel lain yang tidak dapat dijelaskan dalam penelitian ini, seperti Debt to Equity (DER), Quick Ratio (QR), Current Ratio (CR) dan Total Asset Turnover

\section{3) Uji Hipotesis}

a) Uji Simultan (Uji F)

Hasil uji $F$ dalam penelitian ini dapat dilihat pada Tabel 7 .

Tabel 7

Hasil Uji F ANOVA $^{\mathrm{a}}$

\begin{tabular}{|ll|r|c|}
\hline Model & & F & Sig. \\
\hline 1 & $\begin{array}{l}\text { Regression } \\
1\end{array}$ & 5,051 &, $011^{\mathrm{b}}$ \\
& $\begin{array}{l}\text { Residual } \\
\text { Total }\end{array}$ & & \\
\hline & & \\
\hline
\end{tabular}

a. Dependent Variable: PBV

b. Predictors: (Constant), ROA, DAR

Sumber: Hasil Pengolahan Data

Berdasarkan Tabel 7 di atas, hasil uji $\mathrm{F}$ menunjukkan $F_{\text {hitung }}>F_{\text {tabel }}(5,051>3,25)$ maka $\mathrm{H}_{0}$ ditolak, berarti leverage dan profitabilitas berpengaruh signifikan terhadap nilai perusahaan pada Perusahaan Sub Sektor Kimia yang terdaftar di Bursa Efek Indonesia.

b) Uji Parsial (Uji t)

Hasil uji t dalam penelitian ini dapat dilihat pada Tabel 8.

Tabel 8

Hasil Uji t

Coefficients $^{a}$

\begin{tabular}{|c|c|c|c|c|}
\hline \multirow{2}{*}{\multicolumn{2}{|c|}{ Model }} & Standardized & \multirow[t]{2}{*}{$\mathrm{T}$} & \multirow[t]{2}{*}{ Sig. } \\
\hline & & Beta & & \\
\hline \multirow{3}{*}{1} & (Constant) & &,- 165 & ,870 \\
\hline & DAR & 377 & 2,162 & ,037 \\
\hline & ROA & ,547 & 3,134 & ,003 \\
\hline
\end{tabular}

a. Dependent Variable: PBV

Sumber: Hasil Pengolahan Data

Berdasarkan Tabel 8 di atas, untuk variabel leverage, nilai $t_{\text {hitung }}>t_{\text {tabel }}(2,162>$ 2,02619) atau tingkat signifikan 0,037 $<0,05$ maka $\mathrm{H}_{0}$ ditolak. Artinya, leverage berpengaruh signifikan terhadap nilai perusahaan pada Perusahaan Sub Sektor Kimia yang terdaftar di Bursa Efek Indonesia.

Untuk profitabilitas $t_{\text {hitung }}>t_{\text {tabel }}(3,134>$ 2,026 .) atau tingkat signifikansi $0,003<0,05$, maka $\mathrm{H}_{0}$ ditolak. Artinya, profitabilitas berpengaruh signifikan terhadap nilai perusahaan pada Perusahaan Sub Sektor Kimia yang terdaftar di Bursa Efek Indonesia. 


\section{Evaluasi}

a. Evaluasi Leverage pada Perusahaan Sub Sektor Kimia yang terdaftar di Bursa Efek Indonesia

Hasil penelitian menunjukkan pada saat DAR berada pada tingkat maksimum memiliki pengaruh yang baik untuk Perusahaan Sub Sektor Kimia yang terdaftar di Bursa Efek Indonesia periode 2012-2016. Hal ini dikarenakan mayoritas Perusahaan Sub Sektor Kimia ini menggunakan utang yang lebih besar dalam pendanaan perusahaan, dalam hal ini utang yang besar digunakan untuk menambah aset, meningkatkan penjualan sehingga dapat meningkatkan laba pada perusahaanperusahaan tersebut. Dalam hal ini, sebaiknya perusahaan tetap mengoptimalkan penggunaan dana dalam perusahaan sehingga dengan penggunaan utang yang besar tetap mampu meningkatkan laba dan perusahaan memiliki dana internal yang lebih banyak dan tingkat utangnya akan menurun.

\section{b. Evaluasi Profitabilitas pada Perusahaan} Sub Sektor Kimia yang terdaftar di

\section{Bursa Efek Indonesia}

Hasil penelitian ini, pada saat ROA berada pada tingkat minimum tidak baik untuk Perusahaan Sub Sektor Kimia yang terdaftar di Bursa Efek Indonesia dikarenakan pada tahun tersebut mayoritas perusahaan mengalami penurunan penjualan dan lebih banyak menggunakan utang dalam pembiayaan operasionalnya sehingga menghasilkan laba bersih setelah pajak yang kecil. Sebaiknya untuk meningkatkan ROA perusahaan, disarankan kepada manajemen perusahaan untuk meningkatkan penjualan dan lebih efektif dan efisien dalam mengelola seluruh aset perusahaan, tetap memperhatikan aset perusahaan jangan sampai ada aset yang menganggur atau dengan menginvestasikan aset perusahaan dengan tujuan untuk menambah keuntungan dari operasi perusahaan.

c. Evaluasi Nilai Perusahaan pada PT Hanjaya Mandala Sampoerna, Tbk.

Hasil penelitian ini, nilai perusahaan yang berada pada tingkat minimum tidak baik untuk perusahaan karena harga saham perusahaan lebih kecil dibandingkan nilai buku saham perusahaan serta utang yang tinggi menyebabkan nilai perusahaan menjadi turun. Untuk meningkatkan nilai perusahaan, manajemen perusahaan sebaiknya meningkatkan penjualan, mengoptimalkan pengunaan dana dalam perusahaan sehingga dengan penggunaan utang yang besar tetap mampu meningkatkan laba. d. Evaluasi Leverage Terhadap Nilai Perusahaan pada Perusahaan Sub Sektor Kimia ynag terdaftar di Bursa Efek Indonesia

Berdasarkan hasil regresi linier berganda yaitu $\hat{Y}=-0,055+1,502 X_{1}+6,689 X_{2}$, diketahui bahwa leverage memiliki pengaruh positif terhadap nilai perusahaan. Besar pengaruh yang dimaksud adalah 1,502 yang berarti bahwa setiap kenaikan Debt to Assetb Ratio (DAR) sebesar 1 satuan akan diikuti kenaikan Price to Book Value (PBV) sebesar 2,502. Sebaliknya setiap penurunan DAR sebesar 1 satuan akan diikuti penurunan PBV sebesar 1,502 satuan. Hasil tersebut sesuai dengan pendapat Brigham dan Joel (2011:171), perusahaan dengan laba yang lebih tinggi akan mampu membayar dividen tinggi, sehingga sampai tingkat dimana utang yang lebih tinggi menaikkan EPS yang diharapkan, leverage akan meningkatkan harga saham.

e. Evaluasi Profitabilitas Terhadap Nilai Perusahaan pada Perusahaan Sub Sektor Kimia yang terdaftar di Bursa Efek indonesia

Berdasarkan hasil regresi linier berganda yaitu $\hat{Y}=-0,055+1,502 X_{1}+6,689 X_{2}$, profitabilitas berpengaruh positif terhadap nilai perusahaan. Besar pengaruh yang dimaksud adalah 6,689 yang berarti setiap kenaikan ROA sebesar 1 satuan akan diikuti kenaikan PBV sebesar 6,689 satuan. Hasil tersebut sesuai dengan pendapat Brigham dan Joel (2012:150), jika rasio likuiditas, manajemen aset, manajemen utang, dan profitabilitas terlihat baik dan jika kondisi ini berjalan terus menerus secara stabil maka rasio nilai pasar juga akan tinggi, harga saham kemungkinan tinggi sesuai dengan yang diperkirakan, dan manajemen telah melakukan pekerjaannya dengan baik sehingga sebaiknya mendapatkan imbalan. Semakin besar tingkat kemakmuran para investor yang diberikan oleh perusahaan maka akan meningkatkan nilai perusahaan dan berpengaruh positif terhadap harga saham dipasar yang akan meningkatkan nilai perusahaan.

D. KESIMPULAN DAN SARAN

1. Kesimpulan

a. Rata-rata Debt to Asset Ratio (DAR) pada perusahaan Sub Sektor Kimia yang terdaftar di Bursa Efek Indonesia periode 2012-2016 sebesar 0,359 atau 35,9.

b. Rata-rata Return on Asset (ROA) pada perusahaan Sub Sektor Kimia yang terdaftar di Bursa Efek Indonesia periode 2012-2016 sebesar 0,048.

c. Rata-rata Price to Book Value (PBV) pada perusahaan Sub Sektor Kimia yang terdaftar di Bursa Efek Indonesia periode 2012-2016 sebesar 0,806. Hal ini 
menunjukkan bahwa Price to Book Value (PBV) lebih kecil dari nilai bukunya.

\section{Saran}

a. Berdasarkan hasil penelitian disarankan perusahaan tetap mengoptimalkan penggunaan dana dalam perusahaan sehingga dengan penggunaan utang yang besar tetap mampu meningkatkan laba dan perusahaan memiliki dana internal yang lebih banyak dan tingkat utangnya akan menurun.

b. Berdasarkan hasil penelitian sebaiknya untuk meningkatkan ROA perusahaan disarankan kepada manajemen perusahaan agar meningkatkan penjualan dan tetap lebih efektif dan efisien dalam mengelola seluruh aset perusahaan, tetap memperhatikan aset perusahaan jangan sampai ada aset yang menganggur atau dengan menginvestasikan aset perusahaan dengan tujuan untuk menambah keuantungan dari operasi perusahaan walaupun perusahaan tidak beroperasi.

c. Berdasarkan hasil penelitian sebaiknya untuk meningkatkan nilai perusahaan, manajemen perusahaan sebaiknya memperbaiki nilai perusahaannya dengan cara meningkatkan penjualan, mengoptimalkan penggunaan dana sehingga dengan penggunaan utang yang besar tetap mampu meningkatkan laba sehingga dapat meningkatkan nilai perusahaan.

\section{E. DAFTAR PUSTAKA}

Baridwan, Zaki. 2004. Intermediate Accounting. Edisi 8. Yogyakarta : BPFE.

Brigham, Eugene F dan Joel F. Houston. 2001. Manajemen Keuangan Edisi Kedelapan. Jilid satu. Jakarta : Erlangga.

2011. Dasar-Dasar Manajemen Keuangan. Edisi Kesebelas. Jilid 2. Jakarta : Salemba Empat.

Harahap, Sofyan Syafri. 2008. Analisis Kritis atas Laporan Keuangan. Jakarta : PT. Raja Grafindo Persada.

Hery, 2009. Teori Akuntansi. Edisi Pertama. Cetakan Ke-1. Jakarta : Kencana.

Keown, et. al. 2004. Manajemen Keuangan : Prinsip-Prinsip Dasar dan Aplikasi. Jakarta : PT. Indeks Kelompok Gramedia. 2008. Manajemen Keuangan : Prinsip dan Penerapan. Edisi Kesepuluh. Jilid 1. Jakarta : PT. Indeks.

Kasmir, 2010. Pengantar Manajemen Keuangan. Edisi Pertama. Cetakan Pertama. Jakarta : Kencana.

Martani, Dwi, dkk. 2012. Akuntansi Keuangan Menengah. Buku I. Jakarta : Salemba Empat.

Munawir, 2004. Analisa Laporan Keuangan. Edisi Keempat. Cetakan Ketujuhbelas. Yogyakarta : Liberty.

Riyanto, Bambang. 2009. Dasar-Dasar Pembelanjaan Perusahaan. Edisi Keempat. Cetakan Keenam. Yogyakarta. BPFE.

Sudana, I Made. 2011. Manajemen Keuangan Perusahaan Teori dan Praktek. Jakarta : Penerbit Erlangga 